\title{
Septic Abortion and Associated Morbidity and Mortality
}

\author{
Adiba Malik ${ }^{*}$ \\ Kamrun Nessa ${ }^{2}$ \\ Rokeya Begum²
}

'Dept. of Obstetrics \& Gynaecology Chattagram Maa-O-Shishu Hospital Medical College Chittagong, Bangladesh.

${ }^{2}$ Dept. of Obstetrics \& Gynaecology Chittagong Medical College Chittagong,Bangladesh.
*Correspondence to:

\section{Dr. Adiba Malik}

Registrar

Dept. of Obstetrics \& Gynaecology

Chattagram Maa-O-Shishu Hospital Medical College Chittagong, Bangladesh

Mobile: +880-1817732698

\begin{abstract}
Background: In Bangladesh a large number of women attending the major urban hospitals with the complications directly due to abortion like, hemorrhage, fever, peritonitis, visceral injuries. Among all types of abortion, septic abortion is a significant health problem with short and long term complications that affect the quality of life of those fortunate enough to avoid mortality. Aim: This study was conducted to assess the septic abortion related morbidity and mortality in a tertiary level hospital in one year. Methods: This study was a cross sectional observational study in the Department of Obstetrics and Gynaecology, Chittagong Medical college hospital form October 2008 to September 2009, where 60 patients of septic abortions in above period were collected by history examination, management, complications and associated morbidity and mortality. Results : $58.3 \%$ of septic abortion patients came from lower class, $70 \%$ of them were residing in urban slum area, $96.7 \%$ were married $44 \%$ of them were illiterate, $85 \%$ of them did not use any contraceptive methods although they didn't want to increase their family. $78.3 \%$ needed surgical treatment, $23.7 \%$ needed major surgery like laparotomy, average duration of hospital stay was 12.08 days and $8.33 \%$ patients came with septicemic shock and died. Conclusion: Septic abortion is an important contributor to maternal morbidity and mortality, increasing the burden not only the patients but health workers and their resources.
\end{abstract}

Key words: Septic abortion; Morbidity; Mortality.

\section{INTRODUCTION}

Each year an estimated 210 million women become pregnant. Worldwide more than one fourth of these pregnancies will end in abortion or an unplanned birth ${ }^{1}$. Pregnancy places a woman at some risk for illness and death. This risk may be gladly assumed with a desired pregnancy. Unwanted pregnancy places a woman at additional risk if she seeks abortion and safe services are not available ${ }^{2}$. Abortion is the termination of pregnancy by any means before the fetus is sufficiently develop to survive $^{3}$. Any type of abortion when completed with infection it is called septic abortion $^{3}$. Septic abortion continued to be a major health problem in developing countries where abortion is not legalized ${ }^{4}$. Here termination is mostly done by traditional birth attendants or quacks who are available in the vicinity. Once complicated, they are referred to Government hospitals as no one accepts a moribund patients. The infection can occur during or just after an abortion. The infection can result form factors like attempted abortion using infectious tools, lack of proper antiseptic and asepsis, incomplete evacuation, inadvertent injury to the genital organs and adjacent structures particularly gut ${ }^{5}$. Once interference is done infection starts as endometritis involving endometrium and any retained products of conception. If not treated, infection spreads further into myometrium and parametrium. Parametritis progress into peritonitis. The patient may develop bacteremia and sepsis at any stage of septic abortion. Pelvic inflammatory disease is the most common complication of septic abortion and delayed treatment permits the infection to progress to bacteremia, generalized peritonitis, pelvic abscess, disseminated intravascular coagulopathy, adult respiratory distress syndrome, septic shock, renal failure and death $^{4,5,6}$. Present study analyzes the cases of septic abortion in a tertiary hospital to evaluated the socioeconomic and demographic precedent factors, reasons and methods used for termination, clinical features, hospital stay, complications and death with special emphasis on unmet needs of safe abortion. 


\section{MATERIALS AND METHODS}

This was a hospital based cross sectional observational study of 60 patients who were admitted and diagnosed as septic abortion in the Department of Obstetrics and Gynecology in Chittagong $M$ edical college hospital in one year time period between October 2008 to September 2009. A total 60 patients were admitted as emergency cases with symptoms and signs of septic abortion. Clinical data was recorded in the pre designed structured questionnaire, regarding socieo-demographic factors, modes of abortion, clinical features, morbidities (in terms of surgical procedure other than $E \& C$ and $D \& C$., cases needed prolong hospitalization, left with permanent damage like hysterectomy, tuboavarian mass, perforation of uterus, cervical and vaginal injury, acute renal failure, adult respiratory distress syndrome.)

\section{RESULTS}

In this study most of the patients were between 21-30 years of age. Most of them were from low socieo economic class $58.3 \%$, and were residing in urban slum area $70 \%$, and $96.7 \%$ were married.

Table 1: Age groups in septic abortion $(n=60)$

$\begin{array}{llc}\text { A ge in G roups } & \text { n } & \% \\ 18-20 \text { Y ears } & 05 & 8.3 \\ 21-30 \text { Years } & 33 & 55.0 \\ 31-40 \text { Y ears } & 22 & 36.7\end{array}$

Table 2: Socio-demographic factors among the study group $(n=60)$

\begin{tabular}{llcc}
$\begin{array}{c}\text { Socio-demographic } \\
\text { factors }\end{array}$ & n & $\%$ \\
Socio-economic & Lower class & 35 & 58.3 \\
status & L ower middle class & 19 & 31.7 \\
& U pper M iddle class & 06 & 10.0 \\
Habitation & Rural & 17 & 28.3 \\
& Urban & 01 & 1.7 \\
M arital status & Urban slum & 42 & 70.0 \\
& M arried & 58 & 96.7 \\
& Unmarried & 02 & 3.3 \\
\hline
\end{tabular}

$73.4 \%$ of the patients were illiterate and $78.3 \%$ were house wives, $85 \%$ of them did not use any contraceptive methods.

Table 3: Educational levels among the study groups $(n=60)$

\begin{tabular}{lcc}
$\begin{array}{l}\text { Educational levels } \\
\text { of the Patients }\end{array}$ & $\mathbf{n}$ & $\%$ \\
\hline Illiterate & 44 & 73.4 \\
Primary & 14 & 23.3 \\
Secondary & 02 & 3.3 \\
HSC \& above & 00 & 0.0 \\
\hline
\end{tabular}

Table 4 : Occupation among the study subjects $(n=60)$

\begin{tabular}{lcc}
$\begin{array}{l}\text { Occupations } \\
\text { of the Patients }\end{array}$ & $\mathbf{n}$ & $\%$ \\
\hline House wife & 47 & 78.3 \\
Garments worker & 07 & 11.7 \\
M aid servant & 04 & 6.7 \\
Unemployed & 02 & 3.3 \\
\hline
\end{tabular}

Table 5: Contraceptive history among the study groups ( $n=60)$

$\begin{array}{llc}\text { Contraceptive History } & \text { n } & \% \\ \text { OCP } & 05 & 8.3 \\ \text { Condom } & 03 & 5.0 \\ \text { Injectable contraceptives } & 01 & 1.7 \\ \text { Nil } & 51 & 85.0\end{array}$

In $95 \%$ of the cases their was history of induced abortion and termination mostly done by unskilled abortionists $89.5 \%$, reason for termination of pregnancy was not to increase the family size $71.9 \%$.

Table 6: Distribution of modes of abortion among the study group $(n=60)$

\begin{tabular}{lcc} 
M odes of A bortion & $\mathbf{n}$ & $\%$ \\
Spontaneous & 03 & 5.0 \\
Induced & 57 & 95.0 \\
\hline
\end{tabular}

Table 7: History of induced abortion $(n=57)$

\begin{tabular}{llcc}
$\begin{array}{l}\text { History of } \\
\text { Induced Abortion }\end{array}$ & $\begin{array}{c}\text { No. of } \\
\text { Observations }\end{array}$ & $\begin{array}{c}\text { Percentage } \\
\text { (\%) }\end{array}$ \\
\hline $\begin{array}{l}\text { Termination } \\
\text { done by }\end{array}$ & Unskilled abortionist & 51 & 89.5 \\
& M edical Personnel & 06 & 10.5 \\
Reasons for & Not to increase family size & 41 & 71.9 \\
termination & Unwanted pregnancy & 13 & 22.8 \\
& Illegal pregnancy & 02 & 3.5 \\
& Divorce & 01 & 1.8 \\
\hline
\end{tabular}

Surgical treatment needed in $78.3 \%$ patients and major surgery that is laparotomy needed in $34.1 \%$ patients. A mong them, total abdominal hysterectomy needed in $13.4 \%$ and total abdominal hysterectomy and repair and resection anastomosis of gut require in $6.7 \%$ and $3.3 \%$ of the patients, and average duration of hospital stay was 12.08 days.

Table 8: Surgical treatments received among the study group ( $n=60)$

\begin{tabular}{lllc} 
& & n & $\%$ \\
Surgical treatment & Received & 47 & 78.3 \\
& Not received & 13 & 21.7 \\
A mong surgical & E \& C & 25 & 53.2 \\
treatments received & D \& C & 05 & 10.6 \\
& Laparotomy & 16 & 34.1 \\
& Post. colpotomy & 01 & 2.1 \\
\hline
\end{tabular}

Table 9: Laparotomy cases among the study groups $(n=60)$

\begin{tabular}{lcc}
$\begin{array}{l}\text { Laparotomy \& surgical } \\
\text { toileting followed by }\end{array}$ & $\mathbf{n}$ & $\%$ \\
\hline $\begin{array}{l}\text { Repair of uterus } \\
\text { Total abdominal hysterectomy }\end{array}$ & 02 & 3.3 \\
$\begin{array}{l}\text { Total abdominal hysterectomy } \\
\text { + Gut repair }\end{array}$ & 08 & 13.4 \\
$\begin{array}{l}\text { Total abdominal hysterectomy } \\
\text { + Resection anastomosis }\end{array}$ & 04 & 6.7 \\
Nil & 02 & 3.3 \\
\end{tabular}


Table 10: Total hospital stays among the study groups $(n=60)$

\begin{tabular}{ccccc} 
& No. of & \multicolumn{3}{c}{ Days } \\
\cline { 3 - 5 } & Patients & Mean & \pm SD & Range \\
Total Hospital Stay & 60 & 12.08 & 10.65 & $1-42$
\end{tabular}

In terms of complications (morbidities) 15\% presented with hypovolumic shock, $11.6 \%$ generalized peritonitis with septicemia, pelvic peritonitis $25 \%$, perforation of uterus $10 \%$, vaginal and cervical injury $6.66 \%$, acute renal failure $05 \%$, tuboovarian mass $3.3 \%$, A RDS $1.7 \%$, septicemia with jaundice $1.7 \%$ and $8.33 \%$ patients expired in the course of treatment.

Table 11: Complications (morbidities) among the study groups $(n=60)$

\begin{tabular}{lcc} 
Complications & $\mathbf{n}$ & $\%$ \\
Hypovolumic shock & 09 & 15.0 \\
Generalized peritonitis with septicemia & 07 & 11.6 \\
Pelvic peritonitis & 15 & 25.0 \\
Perforation of uterus & 06 & 10.0 \\
Vaginal \& cervical injury & 04 & 6.66 \\
Acute renal failure & 03 & 5.0 \\
Tubo-ovarian mass & 02 & 3.3 \\
ARDS & 01 & 1.7 \\
Septicemia with J aundice & 01 & 1.7 \\
DIC & 00 & 0.0 \\
No major complications & 12 & 20.0 \\
\hline
\end{tabular}

Table 12: Outcomes among the study groups $(n=60)$

\begin{tabular}{lcc}
\hline Outcomes & n & $\%$ \\
Improved \& discharged & 55 & 91.66 \\
Expired & 05 & 8.33
\end{tabular}

\section{DISCUSSION}

This study showed septic abortion contributes more in life threatening complications in women, which usually followed induced and unsafe abortion. Overall abortion rates are similar in the developing and developed world but unsafe abortion is concentrated in developing countries. An estimated 42 million abortions were induced in 2003, and the rate was 29 per 1000 women aged 15-44 years ${ }^{9}$. Present study showed surgical treatment received by $78.33 \%$. A nother study by $\mathrm{N}$ aib et al $(2004)^{4}$ showed need of surgical treatment $99.99 \%$. Major surgery like laparotomy needed in $34.04 \%$ followed by total abdominal hysterectomy $23.32 \%$. A nother study by Naib et al $(2004)^{4}$, Das et al $(2006)^{7}$ found need of hysterectomy $14.28 \%$ and $13.93 \%$ respectively. So many patients of septic abortion sacrifice their obstetretic future in the course of treatment. $M$ any patients had serious complications like pelvic peritonitis $25 \%$, generalized peritonitis with septicemia $11.6 \%$, perforation of uterus $10 \%$, acute renal failure $05 \%$, tuboovarian mass $3.33 \%$, A RDS $1.7 \%$, septicemia with jaundice $1.7 \%$.. This study showed death due to septic abortion was $8.33 \%$. Different study showed Naib et al $(2004)^{4}$ in Pakistan $7.5 \%$, Das et al $(2006)^{7}$ in India $23.21 \%$, Rana et al $(2004)^{8}$ in Nepal 9.7\%.

\section{CONCLUSION}

Septic abortion is a common gynaecological problem requiring hospital admission and treatment. It has serious short term and long term complications affecting womens health and life. Most of the patients need major surgery and prolong hospital stay.It will not only increasing patients suffering but economic burden and work load of health personneles. This tragedy can be preventable and for this we have following recommendations: improvement of existing health services, giving adequate post abortion care, family planning services made accessible and acceptable, M R services should be freely extended and accessible, traditional abortionists should be identified and trained not to cause complications and the restrictive law of abortion of B angladesh should be liberal.

\section{REFERENCES}

1. Curtis $\mathrm{C}$. M eeting Health Care N eeds of Women Experiencing Complications of M iscarriage and U nsafe A bortion: J M idwifery Womens Health. 2007 ; 52(4):368-75.

2. Phillip G Stubblefield, David A Grimes. Septic abortion. New England J M ed. 1994; 331(5) : 310 - 314.

3. J effcoate's Principles of Gynaecology, 7th ed. N ew Delhi, India: J aypee B rothers M edical Publishers (P) L td; $2008 ; 131$ - 138.

4. Naib J M, Siddiqui MI, A fridi B. A reviw of septic induced abortion cases in one year at khyber Teaching Hospital Peshawar. J Ayub M edical College A bbottabad. 2004; 16 (3) 59 - 62.

5. Dutta DC. Text B ook of Obstetrics, 6th ed. Calcutta, India: New central Book A gency (P) Ltd; 2004; 159 - 168.

6. SS Ratnam, K. B hasker Rao, S A rulkumaran. Obstetrics and Gynaecology for Post Graduates 2nd ed. Hyderabad, India: Orient Longman Private Limited; 1999; 01: 220 - 225.

7. Das vinita, A garwal A njoo, M ishra A mita, D eshpande Pretam. Septic abortion. The J ournal of O bstetrics and Gynaecology of India. J obstet Gynecol India 2006; 56 (3): 236 - 239.

8. Rana A, Pradhan N, Gurung G, Singh M. Induced septic abortion: A major factor in maternal mortality and morbidity. J. Obstet Gynaecol. 2004; 30(1): 3-8.

9. Sedgh G, Henshaw S, Singh S, A hman E, Shah IH. Induced abortion: Estimated rates and trends worldwide. Lancet. 2007; 370(9595): $1338-45$ 